University of Nebraska - Lincoln

DigitalCommons@University of Nebraska - Lincoln

Faculty Publications from the Harold W. Manter Laboratory of Parasitology

2006

\title{
A Review of Polylekithum Arnold 1934 and Its Familial Affinities Using Morphological and Molecular Data, with description of Polylekithum catahoulensis sp. nov.
}

\author{
Stephen S. Curran \\ Gulf Coast Research Laboratory, stephen.curran@usm.edu \\ Vasyl V. Tkach \\ University of North Dakota \\ Robin M. Overstreet \\ Gulf Coast Research Laboratory, robin.overstreet@usm.edu
}

Follow this and additional works at: https://digitalcommons.unl.edu/parasitologyfacpubs

Part of the Parasitology Commons

Curran, Stephen S.; Tkach, Vasyl V.; and Overstreet, Robin M., "A Review of Polylekithum Arnold 1934 and Its Familial Affinities Using Morphological and Molecular Data, with description of Polylekithum catahoulensis sp. nov." (2006). Faculty Publications from the Harold W. Manter Laboratory of Parasitology. 424.

https://digitalcommons.unl.edu/parasitologyfacpubs/424

This Article is brought to you for free and open access by the Parasitology, Harold W. Manter Laboratory of at DigitalCommons@University of Nebraska - Lincoln. It has been accepted for inclusion in Faculty Publications from the Harold W. Manter Laboratory of Parasitology by an authorized administrator of DigitalCommons@University of Nebraska - Lincoln. 


\title{
A review of Polylekithum Arnold, 1934 and its familial affinities using morphological and molecular data, with description of Polylekithum catahoulensis sp. nov.
}

\author{
Stephen S. Curran ${ }^{1 *}$, Vasyl V. Tkach ${ }^{2,3}$ and Robin M. Overstreet ${ }^{1}$ \\ ${ }^{1}$ Department of Coastal Sciences, The University of Southern Mississippi, 703 East Beach Drive, Ocean Springs, Mississippi 39564, USA; \\ ${ }^{2}$ Department of Biology, University of North Dakota, P.O. Box 9019, Grand Forks, North Dakota 58202-9019, USA; \\ ${ }^{3}$ Institute of Parasitology, Polish Academy of Sciences, 51/55 Twarda Street, 00-818 Warszawa, Poland
}

\begin{abstract}
The type material of Polylekithum ictaluri, P. halli, and Maculifer chandleri was examined from the United States National Parasite Museum, and we determined that the material was conspecific, making $P$. halli and M. chandleri junior subjective synonyms of $P$. ictaluri. Polylekithum catahoulensis sp. nov. was described from material collected from catfishes at the Catahoula Wildlife Refuge, LaSalle Parish, Louisiana, USA, and compared with P. ictaluri collected from catfishes in Reelfoot Lake, Obion County, Tennessee, USA, and the Pearl River, Hancock County, Mississippi, USA. Polylekithum catahoulensis had smaller eggs (77-88 $\mu \mathrm{m}$ long by $51-63 \mu \mathrm{m}$ wide vs. $94-108 \mu \mathrm{m}$ by $52-76 \mu \mathrm{m})$ and a longer forebody (35-41\% of overall body length vs. 29-34\%). Comparison of more than 2,400 bp long fragments of nuclear ribosomal DNA (complete ITS and partial 28S regions) strongly supported the status of $P$. catahoulensis as a new species. Molecular phylogenetic analysis of $28 \mathrm{~S}$ rDNA gene sequences from Polylekithum as well as representative species from Allocreadiidae, Atractotrematidae, Brachycoeliidae, Callodistomidae, Dicrocoeliidae, Encyclometridae, Gorgoderidae, Haploporidae, Opecoelidae, Plagiorchiidae, and Telorchiidae rooted by Monorchiidae and Lissorchiidae demonstrated that of the families tested, Polylekithum was most closely related to Encyclometridae as a gorgoderoid and not to Allocreadiidae as previously reported. Morphological features of three South American allocreadiids, Allocreadium patagonicum, $P$. percai, and A. pichi were inconsistent with generic diagnoses of Allocreadium and Polylekithum, so we suggested they belonged in a single unnamed genus similar to Creptotrema. Polylekithum catlai from India was assessed from the description and failed to conform to the generic diagnosis of Polylekithum. Morphology of Caudouterina suggested a close relationship with Polylekithum and not Allocreadiidae.
\end{abstract}

\section{Key words}

Digenea, Polylekithum catahoulensis sp. nov., P. ictaluri, P. halli, ITS and 28S rDNA, molecular phylogeny, Allocreadiidae, Encyclometridae, Plagiorchioidea, Gorgoderoidea

\section{Introduction}

Polylekithum ictaluri (Pearse, 1924) was first described as Allocreadium ictaluri Pearse, 1924 infecting the channel catfish, Ictalurus punctatus (Rafinesque, 1818), from Lake Pepin in Wisconsin, USA (Pearse 1924). Mueller and Van Cleave (1932) described Polylekithum halli (Mueller et Van Cleave, 1932) as Allocreadium halli Mueller et Van Cleave, 1932 from the brown bullhead, Ameiurus nebulosus (Lesueur, 1819), from Oneida Lake in New York, USA. However, Van Cleave and Mueller (1934) considered P. halli (as A. halli) a junior synonym of $P$. ictaluri (as $A$. ictaluri) after they examined Pearse's (1924) material. Arnold (1934) assessed these spe- cies and recognized that the extension of the vitelline fields into the forebody precluded them from belonging in Allocreadium Looss, 1900 or other related genera that were then included in Allocreadiidae Looss, 1902. Furthermore, Arnold (1934) did not agree with the assessment by Van Cleave and Mueller (1934) that these species were synonymous. Arnold (1934) erected Polylekithum Arnold, 1934 within Allocreadiidae, simultaneously proposing the new combinations Polylekithum ictaluri and Polylekithum halli and assigning P. halli as type species for the genus without stating why he chose it in favor of the older named species, P. ictaluri. Despite this, Seitner (1951) followed Van Cleave and Mueller's (1934) suggestion and lumped both forms in A. ictaluri (=P. ictaluri). 
Treatment of Polylekithum in Allocreadiidae has remained largely unchallenged. Yamaguti (1958) considered Polylekithum to be a junior synonym of Lepidauchen Nicoll, 1913 in Allocreadiidae, but Yamaguti (1971) considered Polylekithum a distinct genus in Allocreadiidae. Polylekithum continued to be treated as an allocreadiid in all of the most recent works classifying the genus (e.g., Gibson 1996, Hoffman 1999, Caira and Bogéa 2005, Platta and Choudhury 2006). Conflict regarding the placement of Polylekithum in Allocreadiidae lies in studies of larval forms mistakenly attributed to P. ictaluri. Seitner (1951) describing what he thought was the life cycle for $A$. ictaluri (=P. ictaluri), reported ophthalmocercariae (= oculate gymnocephalous variety lacking a stylet) developing in rediae in a gastropod (Pleurocera acuta Raffinesque, 1831) and encysting in the mantle of unionids in the Wabash and Tippecanoe Rivers in Indiana, USA. However, Seitner (1951) observed only wild cercariae and adult worms in his study, and therefore never confirmed that the two were conspecific. Cable (1956) realizing the unlikelihood of such an unusual allocreadiid cercaria (all known allocreadiid cercaria were of the ophthalmoxiphidiocercariae type), suggested that the cercaria of Seitner (1951) probably represented that of Skrjabinopsolus manteri Cable, 1952, a deropristid from sturgeons, and Peters (1961) confirmed this notion. Consequently, no knowledge of the cercariae or metacercarial stages of North American species of Polylekithum exists, and the only known larval stage from Polylekithum is the miracidium of P. ictaluri (see Seitner 1951). As a result, adult features and molecular data must be relied upon for considering familial affinity at the present time.

The purpose of this study was to determine if $P$. ictaluri and $P$. halli are distinct or synonymous by comparing museum specimens; to describe a new species in Polylekithum from material we collected and fortified by comparing ITS $(\mathrm{ITS} 1+5.8 \mathrm{~S}+\mathrm{ITS} 2)$ and partial 28S rDNA gene sequences from the new species with those of P. ictaluri; and to assess the inclusion of Polylekithum in Allocreadiidae using partial 28S rDNA gene sequence analysis.

\section{Materials and methods}

Specimens belonging in Polylekithum were obtained from the blue catfish, Ictalurus furcatus (Valenciennes, 1840), and the channel catfish, I. punctatus from Catahoula Lake, LaSalle Parish, Louisiana, USA, in May 2002; the brown bullhead, A. nebulosus from Reelfoot Lake, Obion County, Tennessee, USA, on 19 October 2003; blue catfish from Pearl River, Hancock County, Mississippi, USA, on 21 October 2004; and from blue catfish from Lake Chotard, Issaquena County, Mississippi, USA, on 22 March 2005.

All digenean specimens were collected from freshly caught fishes dissected in the field or collected after immediate transportation to the Gulf Coast Research Laboratory in Ocean Springs, Mississippi. Live worms were rinsed in $0.85 \%$ saline and either placed in $95 \%$ molecular grade ethanol or killed with hot water and then placed in 5\% neutral phosphate buffered formalin solution. Specimens in formalin were later stained using aqueous hematoxylin (Van Cleave's hematoxylin), buffered using lithium carbonate and butylamine, dehydrated in absolute ethanol, cleared in clove oil, and mounted in Canada balsam on glass slides. Terms used to describe morphological features are from Manter (1970) and Clopton (2004). Drawings were made with the aid of a Wild drawing tube. Measurements are given as ranges in micrometers $(\mu \mathrm{m})$ in the descriptions. Egg measurements are from eggs observed in the distal uterus or metraterm. Specimens were deposited at the United States National Parasite Collection (USNPC), Beltsville, Maryland, USA. We examined the following specimens from USNPC: Polylekithum ictaluri (holotype) USNPC No. 7621, (vouchers on two slides) USNPC No. 97067; Polylekithum halli (cotypes as A. halli) USNPC Nos. 39556, 39586, (vouchers as Maculifer chandleri Harwood, 1935) USNPC Nos. 40601, 40602; and Caudouterina rhyacotriton Martin, 1966 (holotype) USNPC No. 61349, (two paratypes) USNPC No. 61349. In addition, we examined specimens from the British Museum of Natural History (BMNH) and from the Helminthological Collection, Institute of Parasitology, Academy of Sciences of the Czech Republic (IPCAS). These included: Polylekithum percai Ostrowski de Núñez, Brugni et Viozzi, 2000 (one paratype) BMNH 1999.10.19.1; Allocreadium pichi Flores, Brugni et Ostrowski de Núñez, 2004 (one paratype) BMNH 2004.1.16.1-2; and Allocreadium patagonicum Shimazu, Urawa et Coria, 2000 (ten paratypes) IPCAS D-424.

Genomic DNA for molecular analysis was extracted from single ethanol fixed specimens of Polylekithum spp.; Lissorchis kritskyi Barnhart et Powell, 1979; Prosthenhystera obesa (Diesing, 1850); Allocreadium lobatum Wallin, 1909; Megalogonia ictaluri Surber, 1928; Crepidostomum cornutum (Osborn, 1903); Phyllodistomum lacustri (Loewen, 1929); and Saccocoelioides sp. collected from Nicaragua following the protocol of Tkach and Pawlowski (1999) (see Table I for hosts and localities). Approximately 2,500 bp long fragments of nuclear ribosomal DNA spanning the 3 ' end of $18 \mathrm{~S}$ nuclear rDNA gene, ITS region (ITS1+5.8S+ITS2) and 5' end of the 28S (including variable domains D1-D3) were amplified by PCR on an Eppendorf Master Gradient thermal cycler. The process incorporated the forward primers S20T2 (5'GGTAAGTGCAAGTCATAAGC-3') or digl2 (5'-AAGCATATCACTAAGCGG-3') and the reverse primer 1,500R (5'GCTATCCTGAGGGAAACTTCG-3'). The PCR primers and several additional internal primers were used for sequencing; internal forward primers, 300F (5'-CAAGTACCGTGAGGGAAAGTTG-3') and digl2 (5'-AAGCATATCACTAAGCGG-3') and internal reverse primers, d58r (5'-CACGAGCCGAGTGATCCACCGC-3'), ECD2 (5'-CTTGGTCCGTGTTTCAAGACGGG-3'), and 900F (5'-CCGTCTTGAAACACGGACCAAG-3').

The PCR reactions were performed according to protocols described by Tkach et al. (2003). Products were purified directly using Qiagen Qiaquick ${ }^{\mathrm{TM}}$ columns, cycle sequenced 
using ABI BigDye ${ }^{\mathrm{TM}}$ chemistry, alcohol-precipitated, and run on an ABI Prism 3100 ${ }^{\mathrm{TM}}$ automated capillary sequencer. Contiguous sequences were assembled and edited using Sequencher $^{\mathrm{TM}}$ (GeneCodes Corp., ver. 4.1.4) and submitted to GenBank (see accession numbers in Table I).

The new sequences were aligned with several sequences from GenBank previously published by Tkach et al. (2001) and Olson et al. (2003) (see Table I). Sequences were aligned initially with the aid of ClustalX using default parameters (Jeanmougin et al. 1998), and alignments were refined by eye using MacClade ver. 4.03 (Maddison and Maddison 2000). The full alignment was deposited with EBI and is available by anonymous FTP from FTP.EBI.AC.UK in directory/pub/databases/embl/align and from the EMBLALIGN database through SRS at http://srs.ebi.ac.uk (instructions on retrieval can be found at http://www3.ebi.ac.uk/Services/webin/help/ webin-align/align_SRS_help.html) under accession ALIGN 001040; exclusion sets were added as comments. Regions that could not be aligned unambiguously were excluded from analyses. Maximum Parsimony (MP) and Maximum Likelihood (ML) were performed using PAUP* (Swofford 2002 ver. 4.0b10). Nodal support was calculated based on 1,000 bootstrap replicates using both MP algorithm (100 replicates at each step) and ML algorithm (100 replicates at each step).

\section{Results}

\section{Polylekithum ictaluri (Pearse, 1924) (Fig. 1)}

Syns: Allocreadium ictaluri Pearse, 1924, Allocreadium halli Mueller et Van Cleave, 1932, Polylekithum halli (Mueller et Van Cleave, 1932), Maculifer chandleri (Harwood, 1935)

\section{Supplemental data}

Based on one specimen from Tennessee and two from Mississippi: Body elongate, oval, 3,003-4,014 long, 758-1,066 wide. Diffuse eyespots lacking. Tegument spineless, with sparsely arranged minute papillae. Oral sucker slightly subterminal, 323-438 long, 206-495 wide. Prepharynx very short, indistinct. Pharynx 207-279 long, 201-207 wide. Oesophagus very short, indistinct. Caeca bifurcating immediately posterior to pharynx, with anterior bulge on both sides of pharynx, terminating near posterior end of body. Post-caecal space 135-168 long, 3-6\% of body length. Ventral sucker nearly circular, 390-663 long, 290-674 wide. Ratio of oral to ventral sucker width 1:1.4. Forebody 1,038-1,150 long, 29-34\% of body length.

Testes immediately tandem, intercaecal in hindbody, with margins entire; anterior testis 195-224 long, 139-393 wide; posterior testis 245-416 long, 127-326 wide. Cirrus sac ellipsoid, 189-416 long, 100-416 wide, containing looping seminal vesicle, pars prostatica and ejaculatory duct; ejaculatory duct opening into small genital atrium; cirrus sac orientation slightly or greatly diagonal, with posterior end sinistral, terminating at ventral sucker anterior margin or level within anterior third of ventral sucker. Genital pore medial (sometimes median) in forebody, midway between caecal bifurcation and ventral sucker margin.

Ovary subspherical, medial, immediately posterior to ventral sucker, 139-224 long, 134-258 wide. Mehlis' gland roughly triangular, dorsal, occurring on either side of ovary, in widest part of body. Seminal receptacle orbicular, 167-212 long, 178 wide, submedian, immediately posterior to ovary, ventral to Mehlis' gland. Laurer's canal not observed. Uterus largely in middle third of body, covering ventral portion of anterior testis. Metraterm dorso-lateral to cirrus sac. Eggs operculate, 94-108 long, 52-76 wide. Vitelline follicles in indistinct lateral fields from level of pharynx to posterior body end, interrupted at level of ventral sucker, confluent dorsally at level of pharynx and broadly confluent posterior to level of testes. Vitelline reservoir ventro-median, immediately posterior to ovary.

Excretory vesicle appearing I-shaped (possibly Y-shaped); main stem reaching anteriorly to vicinity of ovary; collecting arms extending anteriorly around ventral sucker and reaching to level of pharynx. Pore terminal.

Host/locality/collection date: Brown bullhead, Ameiurus nebulosus (Lesueur, 1819) (Siluriformes, Ictaluridae) from Reelfoot Lake, Obion County, Tennessee, USA $\left(36^{\circ} 22^{\prime} 55^{\prime \prime} \mathrm{N}\right.$, $\left.89^{\circ} 21^{\prime} 21^{\prime \prime} \mathrm{W}\right), 19$ October 2003; blue catfish, Ictalurus furcatus (Valenciennes, 1840) (Siluriformes, Ictaluridae) from Pearl River, Hancock County, Mississippi, USA $\left(30^{\circ} 16^{\prime} 51^{\prime \prime} \mathrm{N}\right.$, $\left.89^{\circ} 37^{\prime} 49^{\prime \prime} \mathrm{W}\right), 21$ October 2004; blue catfish from Lake Chotard, Issaquena County, Mississippi, USA (32³4'59"N, $\left.91^{\circ} 01^{\prime} 36^{\prime \prime} \mathrm{W}\right), 22$ March 2005.

Site: Intestine.

Specimens deposited: One voucher specimen, USNPC No. 99087.

\section{Remarks}

Examination of the holotype of P. ictaluri (as A. ictaluri, USNPC No. 7621) indicated that the specimen was not fixed with heat, but it was preserved in relatively good condition. Pearse (1924) described the egg size as $80 \mu \mathrm{m}$ long by $45 \mu \mathrm{m}$ wide (e.g., Pearse 1924), but our measurements of eggs relatively close to the metraterm in the holotype ranged from 89-90 $\mu \mathrm{m}$ long with some eggs measuring $95 \mu \mathrm{m}$ long. Egg measurements from vouchers of $P$. ictaluri from Winnipeg, Canada (USNPC No. 97067), ranged from 90-105 $\mu \mathrm{m}$ long. Mueller and Van Cleave (1932) reported that $A$. halli was very similar to $A$. ictaluri but differed mainly by having larger eggs; measurements, however, were not reported. Yamaguti (1971) reported egg size for $P$. halli from material of Mueller and Van Cleave (1932) as 87-99 $\mu \mathrm{m}$ long by 59-70 $\mu \mathrm{m}$ wide. We examined the type material of $P$. halli (as $A$. halli, USNPC Nos. 39556, 39586) and material named M. chandleri (USNPC Nos. 40601, 40602) that Yamaguti (1971) considered to be $P$. ictaluri, and determined that egg sizes from all of these specimens ranges from 90-105 $\mu \mathrm{m}$ long, matching the same range reported for $P$. ictaluri. Our observations of type and voucher material from $P$. ictaluri and $P$. halli as well as corresponding geographical data suggest that no difference 
exists between the two named forms. Consequently, we agree with Van Cleave and Mueller (1934) and consider $P$. halli to represent a junior subjective synonym of $P$. ictaluri. Moreover, we agree with Yamaguti (1971) and consider M. chandleri to be a junior subjective synonym of $P$. ictaluri.
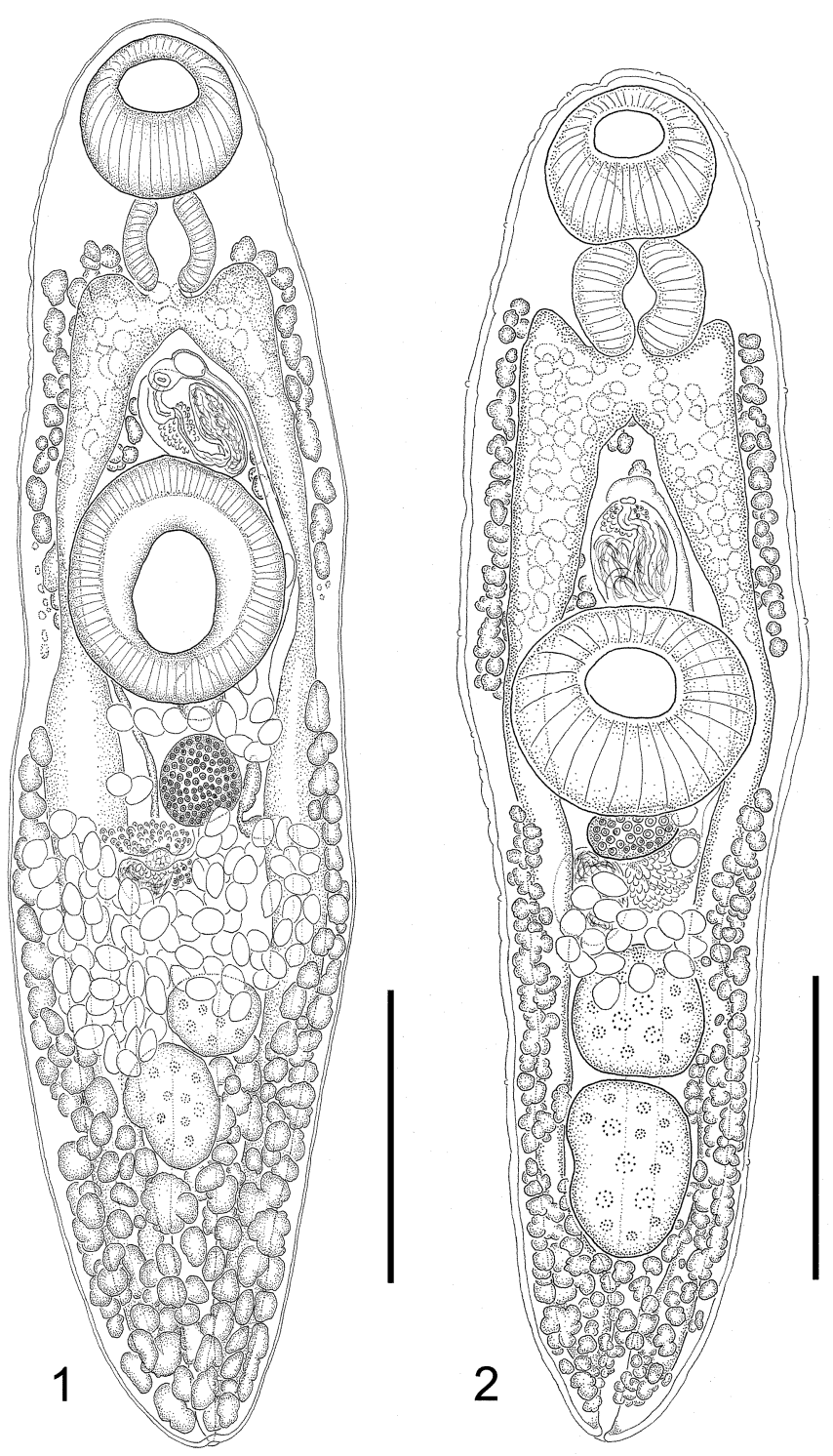

Fig. 1. Polylekithum ictaluri from the intestine of Ameiurus nebulosus from Reelfoot Lake, Tennessee, USA; ventral view. Scale bar = $1 \mathrm{~mm}$. Fig. 2. Polylekithum catahoulensis sp. nov. from the intestine of Ictalurus furcatus from Catahoula Lake, Louisiana, USA; ventral view. Scale bar $=750 \mu \mathrm{m}$

\section{Polylekithum catahoulensis sp. nov. (Fig. 2)}

\section{Description}

Based on 5 whole mounted specimens: Body elongate, oval, 2,060-3,312 long, 472-908 wide. Diffuse eyespots lacking. Tegument spineless, with sparsely arranged minute papillae.
Oral sucker subterminal, 234-362 long, 240-396 wide; posterior margin truncate (rounded in smaller specimens). Prepharynx very short, indistinct. Pharynx 173-296 long, 145-307 wide. Oesophagus very short, indistinct. Caeca bifurcating immediately posterior to pharynx, with anterior bulges on both sides of pharynx, terminating near posterior end of body. Post-caecal space 78-128 long, 3-5\% of body length. Ventral sucker nearly circular, 307-513 long, 323-573 wide, situated at widest part of body. Ratio of oral to ventral sucker width 1:1.4-1.5. Forebody $742-1,291$ long, 35-41\% of body length.

Testes immediately tandem, intercaecal in hindbody, with entire margins; anterior testis 223-335 long, 189-307 wide; posterior testis 268-435 long, 195-435 wide. Cirrus sac ellipsoid, 240-329 long, 100-195 wide, containing looping seminal vesicle, pars prostatica and ejaculatory duct; ejaculatory duct opening into small medial genital atrium; cirrus sac oriented slightly diagonal, with posterior end sinistral, terminating at level within anterior third of ventral sucker. Genital pore median or slightly submedian in forebody, midway between caecal bifurcation and ventral sucker margin.

Ovary subspherical, medial at posterior margin of ventral sucker, 117-139 long, 117-217 wide. Mehlis' gland roughly triangular, dorsal and medial, on either side of ovary. Seminal receptacle 234 long, 178 wide, medial, immediately posterior to ovary, ventral to Mehlis' gland. Laurer's canal not observed. Uterus intercaecal, largely confined to pretesticular region of hindbody (ventrally covering part of anterior testis in most specimens). Metraterm dorso-lateral to cirrus sac. Eggs operculate, 77-88 long, 51-63 wide. Vitelline follicles in two indistinct lateral fields; fields confluent and reaching to pharyngeal level anteriorly and confluent at posterior end of body; both fields interrupted laterally at level of ventral sucker. Vitelline reservoir ventro-medial, immediately posterior to ovary.

Excretory vesicle appearing I-shaped (possibly Y-shaped); main stem reaching anteriorly to vicinity of ovary; collecting arms extending anteriorly around ventral sucker and extending to level of pharynx. Pore terminal.

Type host: Blue catfish, Ictalurus furcatus (Valenciennes, 1840) (Siluriformes, Ictaluridae).

Other host: Channel catfish, Ictalurus punctatus (Rafinesque, 1818) (Siluriformes, Ictaluridae).

Type locality: Catahoula Lake, LaSalle Parish, Louisiana, USA $\left(31^{\circ} 29^{\prime} 22^{\prime \prime} \mathrm{N}, 92^{\circ} 07^{\prime} 55^{\prime \prime} \mathrm{W}\right)$, May 2002.

Site: Intestine.

Specimens deposited: Holotype USNPC No. 99088; one paratype USNPC No. 99098.

Etymology: The species name catahoulensis is named for the region of its discovery within the lower Mississippi River Basin.

\section{Remarks}

Polylekithum catahoulensis sp. nov. from blue and channel catfishes from the Catahoula Lake Wildlife Refuge conformed to the generic diagnosis for Polylekithum given by Caira and 


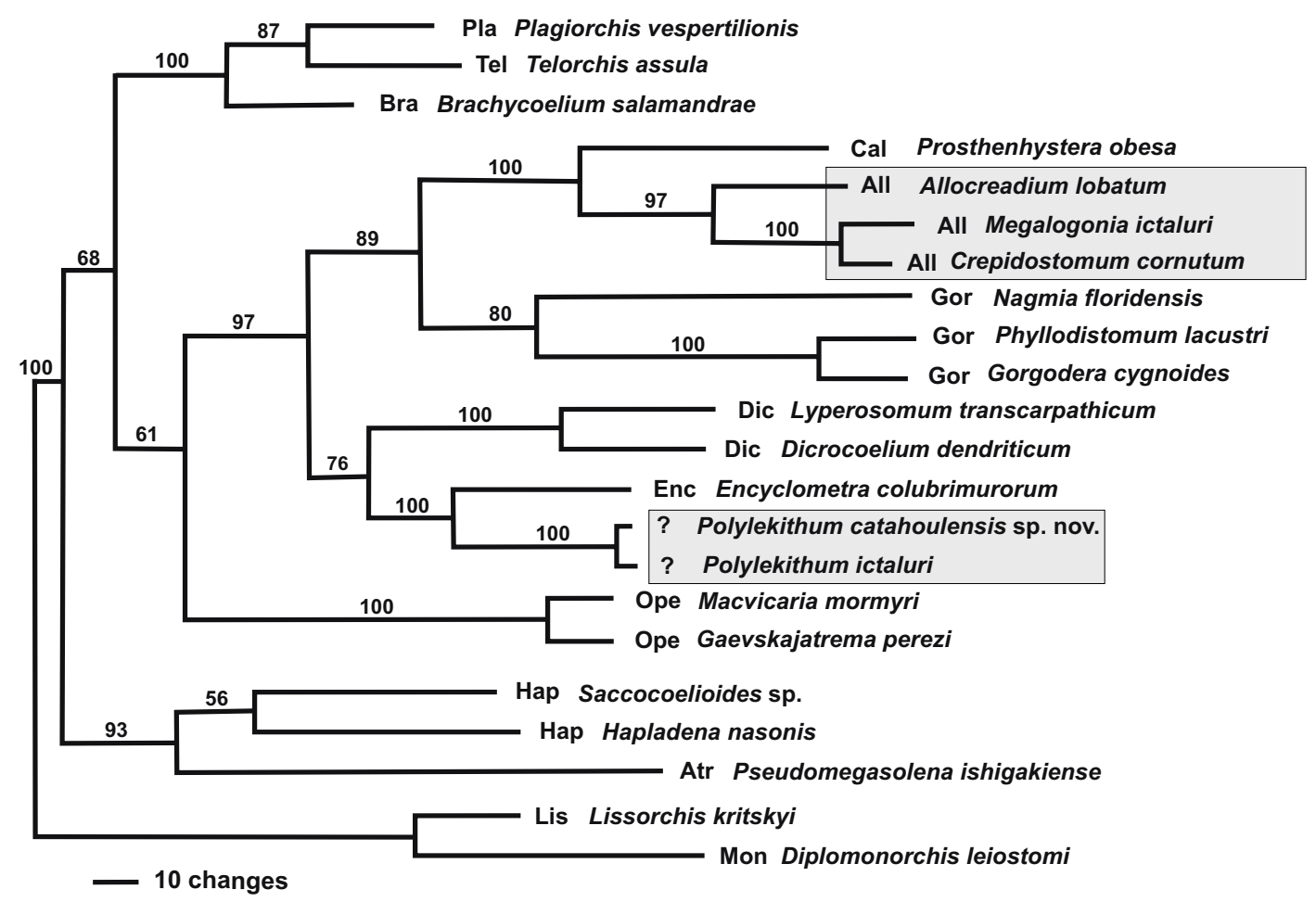

Fig. 3. Phylogenetic tree based on analysis of partial sequences of $28 \mathrm{~S}$ rDNA gene using maximum likelihood algorithm in PAUP*. Bootstrap support values $(1,000$ bootstraps with 100 replicates at each step) are shown above internodes. Shaded rectangles demonstrate that the two studied species of Polylekithum do not belong to the Allocreadiidae

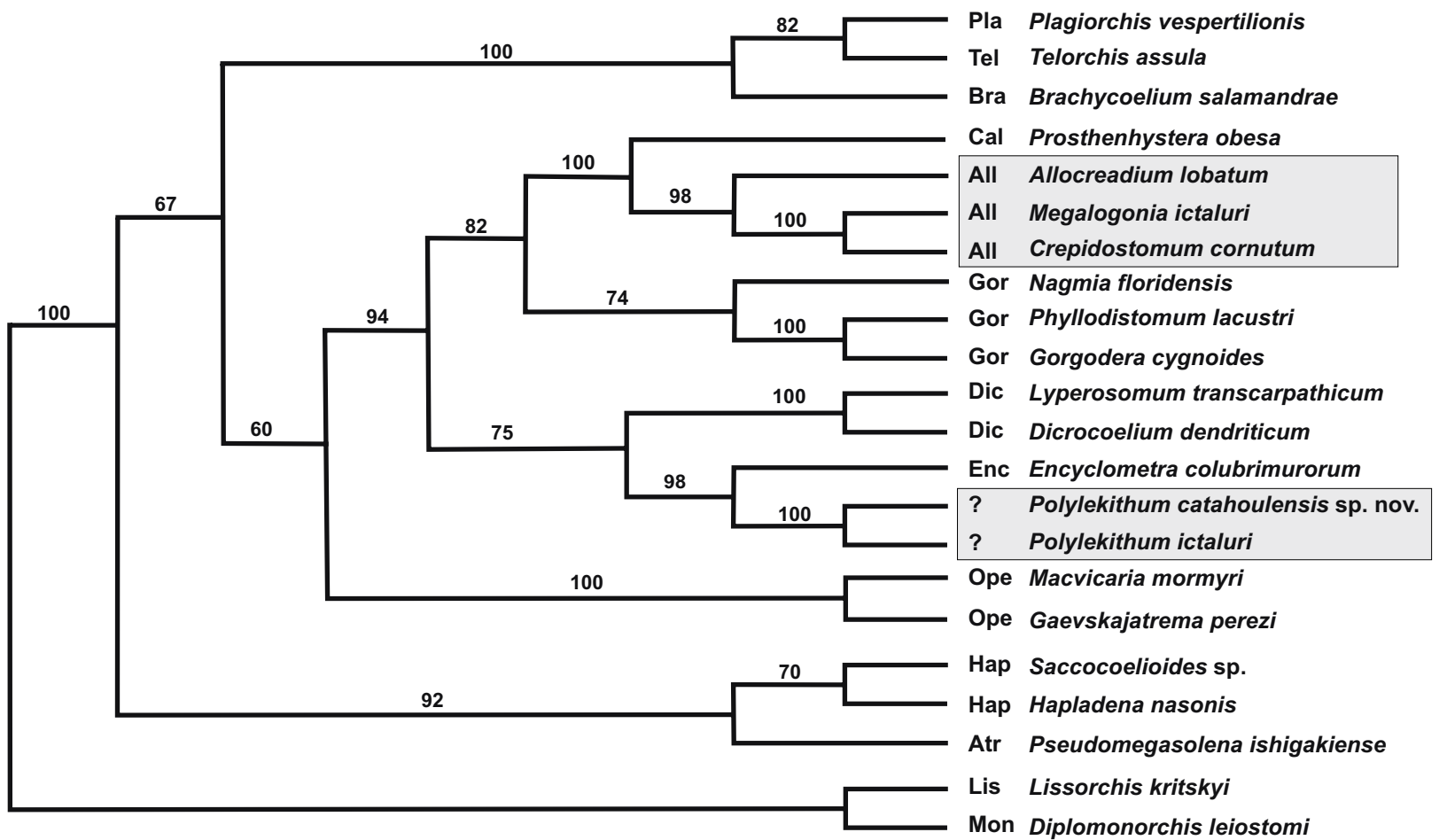

Fig. 4. Phylogenetic tree based on analysis of partial sequences of $28 \mathrm{~S}$ rDNA gene using maximum parsimony algorithm in PAUP*. Bootstrap support values (1,000 bootstraps with 100 replicates at each step) are shown above internodes. Shaded rectangles demonstrate that the two studied species of Polylekithum do not belong to the Allocreadiidae 
Bogéa (2005). The new species is similar morphologically to $P$. ictaluri, but it differs by having smaller eggs $(77-88 \mu \mathrm{m}$ long by $51-63 \mu \mathrm{m}$ wide vs. $88-108$ by $52-76 \mu \mathrm{m}$ ). In addition, the forebody is relatively longer in $P$. catahoulensis measuring $35-41 \%$ of overall body length vs. $29-34 \%$. The widest part of the body occurs at the level of the ventral sucker in P. catahoulensis and at the level of the ovarian complex in P. ictaluri but we do not consider this a diagnostic feature because the body width at the level of the ovarian complex probably de- pends on the number of eggs in the uterus. All of our specimens of $P$. catahoulensis had relatively few eggs in the uterus and all mature specimens of $P$. ictaluri had many eggs, but we examined relatively few individuals of each species.

\section{Molecular analysis}

Molecular data were used for two main goals: (1) specieslevel comparison among samples of Polylekithum to verify existence of a second species in North America and (2) for

Table I. Digenean species used in this study, their hosts, geographical origin of material and GenBank accession numbers for corresponding sequences. Digenean families are listed in alphabetical order for convenience. New sequences are marked with asterisk

\begin{tabular}{|c|c|c|c|}
\hline Digenean taxa & Host species & Geographic origin & GenBank Acc. No. \\
\hline Polylekithum ictaluri & Blue catfish Ictalurus furcatus (F) & Pearl River, Mississippi, USA & EF032697* \\
\hline Polylekithum catahoulensis sp. nov. & Blue catfish Ictalurus furcatus (F) & Catahoula Lake, Louisiana, USA & EF032698* \\
\hline \multicolumn{4}{|l|}{ Allocreadiidae } \\
\hline Allocreadium lobatum & Fallfish Semotilus corporalis (F) & Moosehead Lake, Maine, USA & EF032693* \\
\hline Megalogonia ictaluri & Channel catfish Ictalurus punctatus $(\mathrm{F})$ & Pearl River, Mississippi, USA & EF032694* \\
\hline Crepidostomum cornutum & Warmouth Lepomis gulosus $(\mathrm{F})$ & Pascagoula River, Mississippi, USA & EF032695* \\
\hline $\begin{array}{l}\text { Atractotrematidae } \\
\text { Pseudomegasolena ishigakiense }\end{array}$ & Rivulated parrotfish Scarus rivulatus (F) & Heron Island, Australia & AY222266 \\
\hline \multicolumn{4}{|l|}{ Brachycoeliidae } \\
\hline Brachycoelium salamandrae & Fire salamander Salamandra salamandra (A) & $\begin{array}{c}\text { Near Rahiv, Zakarpatska region, } \\
\text { Ukraine }\end{array}$ & AF151935 \\
\hline $\begin{array}{l}\text { Callodistomidae } \\
\text { Prosthenhystera obesa }\end{array}$ & Channel catfish Ictalurus punctatus $(\mathrm{F})$ & Pearl River, Mississippi, USA & EF032690* \\
\hline \multicolumn{4}{|l|}{ Dicrocoeliidae } \\
\hline Dicrocoelium dendriticum & Steppe marmot Marmota bobak (M) & Kharkiv region, Ukraine & AF151939 \\
\hline Lyperosomum transcarpathicum & Pygmy shrew Sorex minutus (M) & Zakarpatska region, Ukraine & AF151943 \\
\hline \multicolumn{4}{|l|}{ Encyclometridae } \\
\hline \multicolumn{4}{|l|}{ Gorgoderidae } \\
\hline Nagmia floridensis & Atlantic stingray Dasyatis sabina $(\mathrm{F})$ & Ocean Springs, Mississippi, USA & EF032691* \\
\hline Gorgodera cygnoides & Pool frog Rana lessonae (A) & Geneva, Switzerland & AF151938 \\
\hline Phyllodistomum lacustri & Black bullhead Ameiurus melas (F) & North Dakota, USA & EF032692* \\
\hline \multicolumn{4}{|l|}{ Haploporidae } \\
\hline Hapladena nasonis & Blue-spine unicornfish Naso unicornis (F) & Lizard Island, Australia & AY222265 \\
\hline Saccocoelioides sp. & Unidentified molly (Poecilidae) (F) & Rio Campusano, Nicaragua & EF032696* \\
\hline \multicolumn{4}{|l|}{ Lissorchiidae } \\
\hline $\begin{array}{l}\text { Monorchidae } \\
\text { Diplomonorchis leiostomi }\end{array}$ & Spot Leiostomus xanthurus (F) & $\begin{array}{c}\text { Gulf of Mexico, Ocean Springs, } \\
\text { Mississippi, USA }\end{array}$ & AY222252 \\
\hline \multicolumn{4}{|l|}{ Opecoelidae } \\
\hline Macvicaria mormyri & Unidentified $(\mathrm{F})$ & near Corsica, Mediterranean Sea & AF184256 \\
\hline Gaevskajatrema perezi & Unidentified $(\mathrm{F})$ & near Corsica, Mediterranean Sea & AF184255 \\
\hline \multicolumn{4}{|l|}{ Plagiorchiidae } \\
\hline \multicolumn{4}{|l|}{ Telorchiidae } \\
\hline
\end{tabular}

Abbreviations: A - amphibian, F - fish, M - mammal, R - reptile. 
phylogenetic inference to find out phylogenetic affinities and possibly proper systematic position of the genus Polylekithum. A DNA fragment encompassing the complete ITS rDNA region (ITS1+5.8S+ITS2) and about 1,300 bases at the 5' end of the 28S rDNA gene was used for species-level comparison between $P$. ictaluri and $P$. catahoulensis. The alignment was 2,443 bases long and needed introduction of only two gaps. The sequence of $P$. ictaluri was 2,441 bases long, while the sequence of $P$. catahoulensis was 2,443 bases long. The alignment contained 27 variable sites $(1.1 \%$ of all 2,443 sites $)$ distributed across the whole compared fragment, and that strongly supported the status of $P$. catahoulensis as a new species.

For analysis of the phylogenetic position of Polylekithum, a fragment at 5' end of 28S rDNA gene encompassing D1-D3 variable domains, was used. Based on the phylogenetic trees of the Digenea published by Olson et al. (2003), Diplomonorchis leiostomi Hopkins, 1941 (Monorchiidae Odhner, 1911) and Lissorchis kritskyi (Lissorchiidae Poche, 1926) were selected as outgroups while both studied species of Polylekithum and 17 other species belonging to families Allocreadiidae, Atractotrematidae Yamaguti, 1939, Brachycoeliidae Looss, 1899, Callodistomidae Odhner, 1910, Dicrocoeliidae Odhner, 1910, Encyclometridae Baylis et Cannon, 1924, Gorgoderidae Looss, 1901, Haploporidae Nicoll, 1914, Opecoelidae Ozaki, 1925, Plagiorchiidae Lühe, 1901, and Telorchiidae Dollfus, 1925, were included in the ingroup (Table I, Figs 3 and 4). Alignment contained a total of 1,275 sites, of these 1,122 could be aligned unambiguously. Of the aligned positions, 456 were variable and 356 variable positions were parsimony-informative.

Both ML and MP analyses yielded identical tree topology with high bootstrap support of most nodes (Figs 3 and 4). Allocreadiids (excluding Polylekithum) were placed in a clade consisting of the allocreadiids A. lobatum, M. ictaluri, and C. cornutum plus the callodistomid $P$. obesa. The two species of Polylekithum grouped conspicuously outside the allocreadiid clade with Encyclometra colubrimurorum (Rudolphi, 1819) in both analyses.

\section{Discussion}

\section{Two North American species}

Based on our observations of museum specimens and fresh material, we concluded that $P$. ictaluri and $P$. halli are indistinguishable; therefore, we agree with Van Cleave and Mueller (1934), Seitner (1951), and Gibson (1996) and consider $P$. halli a junior subjective synonym of $P$. ictaluri. Furthermore, we agree with Yamaguti (1971) and consider M. chandleri a junior synonym of $P$. ictaluri (see Harwood 1935).

Polylekithum catahoulensis is morphologically very similar to $P$. ictaluri, with its smaller egg size and longer forebody being the obvious morphological features useful for distinguishing the new species, but the level of differences found in the ITS rDNA and partial 28S rDNA sequences of $P$. ictaluri and $P$. catahoulensis clearly demonstrates these two forms are different species. The observed level of differences is similar or exceeds the levels of interspecific variability reported for several groups of digeneans (e.g., Tkach et al. 2000, Jousson and Bartoli 2001, 2002; Snyder and Tkach 2001; Overstreet $e t$ al. 2002; Platt and Tkach 2003; for more references see Olson and Tkach 2005). Of 27 variable sites, 6 were found in the ITS1 rDNA region (1.3\% of 456 sites), while 10 were found in the ITS 2 rDNA region ( $2.6 \%$ of 378 sites) and 10 occurred in the fragment of $28 \mathrm{~S}$ rDNA gene encompassing D1-D3 variable domains $(0.75 \%$ of 1,328 sites). Each of these regions separately would be sufficient to differentiate between the two species of Polylekithum, although our data suggest that ITS2 rDNA is the most practical target for quick differentiation among species of Polylekithum due to its high variability and short length. Only one variable site was found in the $124 \mathrm{bp}$ long fragment at 3 ' end of the ribosomal $18 \mathrm{~S}$ gene and no variability was observed in the $157 \mathrm{bp}$ long 5.8S rDNA gene, suggesting these regions are too conserved to provide useful data for differentiating species of Polylekithum.

We attempted to compare our sequences with an $804 \mathrm{bp}$ long fragment of 28S rDNA gene from Polylekithum ictaluri (GenBank No. DQ189999), sequenced by Platta and Choudhury (2006). Unfortunately, the comparison showed that sequence DQ189999 contained many inaccuracies. When compared to our sequences, base pair incongruence exhibited by DQ189999 greatly exceeded what would be expected for a species in the same genus. The inaccuracies may have been caused by sequencing software signal misreading, which frequently occurs, but the tail end of the sequence DQ189999 (approximately $80 \mathrm{bp}$ ) did not align with any digenean, suggesting there were errors in the methodology used by Platta and Choudhury (2006). Platta and Choudhury (2006) used only a part (less than a half) of the sequence DQ189999 in their phylogenetic analysis; however, we cannot speculate to what extent, if any, the above sequence inaccuracies influenced their results because no alignment was deposited in a web-based database. Given these problems, we suggest sequence DQ189999 be treated with some caution when incorporated into future works.

Though specific to ictalurids, the two species are not hostspecific to particular catfish. Polylekithum ictaluri has been reported from a variety of catfish hosts, including A. nebulosus (see Mueller and Van Cleave 1932, Arnold 1934, Van Cleave and Mueller 1934) and both I. furcatus and I. punctatus (see Pearse 1924, Seitner 1951). Harwood (1935) reported $P$. ictaluri (as M. chandleri) from freshwater catfishes in Texas. Polylekithum catahoulensis infects both I. punctatus and I. furcatus.

\section{Classification of Polylekithum}

Prior to this study, Polylekithum was included in Allocreadiidae, but morphological features suggest that the genus does not belong in any of the freshwater families that have a smooth tegument and use fish as their definitive hosts. Species 
of Polylekithum share extensive vitelline fields with those belonging in Allocreadiidae, but, unlike in all allocreadiids, the metraterm lies lateral on the sinistral side of the cirrus sac rather than ventral to it and the forebody in adults lacks diffuse eyespots, suggesting that cercariae are not ophthalmoxiphidiocercariae. Extensive vitelline fields and lack of diffuse eyespot pigments also exclude Polylekithum from Callodistomidae. Polylekithum resembles members of Opecoelidae by lacking diffuse eyespots in the forebody, and a genital pore that is more or less slightly sinistral but the metraterm lies sinistral to the cirrus sac rather than dorsal to it as in Opecoelidae. Adult specimens in Polylekithum also share with cercariae of Gorgoderidae a smooth tegument having intermittently placed surface papillae. However, extensive vitellaria, the presence of a cirrus sac, and a lateral rather than ventral metraterm (relative to the male terminal genital complex) exclude the genus from Gorgoderidae. Furthermore, we observed excretory branches leading anteriorly on either side of the ventral sucker and extending to the level of the pharynx. These may well represent secondary arms associated with a Y-shaped excretory bladder. Allocreadiids all have I-shaped bladders, and secondary excretory arms are not prominent in the forebodies of allocreadiids. We consequently refute the convention of treating Polylekithum in Allocreadiidae or other freshwater fish digenean families based solely on morphological observations of adult specimens.

The tree topology we obtained (Figs 3 and 4) is generally in agreement with topologies published previously (e.g., Tkach et al. 2001, Olson et al. 2003). Inclusion of Saccocoelioides sp., Polylekithum spp., and several allocreadiids produced the only differences between our tree topology and that of Olson et al. (2003). Platta and Choudhury (2006) included allocreadiids plus $P$. ictaluri in their analysis, but they did not include gorgoderids, callodistomids and certain other related Xiphidiata (non-allocreadiid taxa were represented only by members of the Plagiorchioidea), therefore, their topology somewhat artificially placed Polylekithum adjacent to or included with the allocreadiids depending on one's interpretation. For the same reason, the conclusion by Platta and Choudhury (2006) that Paracreptotrematina limi Amin et Myer, 1982 is an allocreadiid also needs additional confirmation, using a wider taxonomic representation of xiphidiatan digeneans and longer sequences.

Our analysis (Figs 3 and 4) showed without doubt that Polylekithum is not an allocreadiid. Unfortunately, assigning Polylekithum to an existing or new family is not possible based solely on our data. The tree topology resulting from our analysis may lack some unknown or overlooked plagiorchioid taxon or taxa more closely related to Polylekithum than Encyclometridae. Polylekithum is most similar morphologically to Caudouterina Martin, 1966, and Leurosoma Ozaki, 1932, genera also provisionally treated in Allocreadiidae (see Martin 1966, Yamaguti 1971, Caira and Bogéa 2005). Likely, these three genera share some familial affinity in the Xiphidiata based on morphological comparison. All have a smooth tegument, extensive vitellaria, a slightly sinistral genital pore, metraterm lying adjacent to the cirrus sac, caeca reaching to near the posterior body end, extensive uterus (may be somewhat confined in Polylekithum), and freshwater life cycle. All three genera violate the allocreadiid diagnosis by lacking pigmented eyespots and not having the metraterm ventral to the cirrus sac. Caudouterina rhyacotritoni, the only species in the genus from the intestine of the Olympic torrent salamander, Rhyacotritoni olympicus (Gaige, 1917), in streams draining into the Pacific Ocean in Oregon, USA, differs from Polylekithum spp. by having oblique rather than tandem testes and by having the uterus descend between the testes to the posterior body end. Species of Leurosoma occur in turtles in Asia and snakes in South America and differ from Polylekithum spp. by having a long oesophagus and very small eggs (e.g., Yamaguti 1971, Kohn and Fernandes 1976). Unfortunately, like with Polylekithum, no life history information is available for Caudouterina or Leurosoma, and of the three genera our molecular analyses included only Polylekithum. Regardless of which taxa may or may not have been omitted from our analyses, the results convincingly demonstrate that Polylekithum does not belong to Allocreadiidae and is strongly linked to Encyclometridae (Fig. 3). Encyclometridae is a freshwater family in Gorgoderoidea containing the single Eurasian genus Encyclometra Baylis et Cannon, 1924. Species of Encyclometra parasitize the digestive tract of snakes and metacercariae occur in freshwater fish and amphibians (Yamaguti 1971). Polylekithum shares a morphological resemblance to species in Encyclometra, but Encyclometra spp. have eggs with miracidial eyespots and their vitellarium does not extend into the forebody. Consequently, we doubt that Polylekithum belongs in Encyclometridae. Polylekithum, Caudouterina, and possibly Leurosoma, may belong in a new family, but without acquiring the appropriate additional sequences or knowledge of their life histories for comparison, we hesitate to erect a new family. Other important morpho-anatomical data are also missing such as chaetotaxy or excretory flame-cell formula. We did not have cercariae or young specimens suitable for counting flame cells but we anticipate that the number of protonephridia in species of Polylekithum will be rather high because a count of 140 occurs in a species of Enyclometra (Odening $1960,1968)$. In contrast, allocreadiids have fewer protonephridia. Caira (1989) reported protonephridial counts ranging from 24 to 38 for at least six allocreadiid species.

In addition to showing that Polylekithum does not belong in Allocreadiidae, the phylogenetic trees we presented also enhance the overall knowledge of relationships in Xiphidiata. Olson et al. (2003) considered lack of representatives of the Allocreadiidae an important omission from their analysis, the most comprehensive molecular phylogenetic study of the Digenea available today. Platta and Choudhury (2006) obtained about 800 bp long 28S rDNA sequences of three members of the Allocreadiidae; however, these authors did not place their sequences in a wider phylogenetic context. Our study partly closes this gap by including the allocreadiid genera Allocreadium, Crepidostomum Braun, 1900, and Megalogonia Surber, 1928 and shows that Allocreadiidae is close to 
Callodistomidae and Gorgoderidae but is somewhat more distant from Opecoelidae than considered by Olson et al. (2003). Consequently, the superfamilies of Xiphidiata incorporated by Olson et al. (2003) need reevaluation. Clearly, Allocreadioidea Looss, 1902 should not contain Opecoelidae + Opistholebetidae Fukui, 1929. Opistholebetids are a small group of marine species having a postoral muscular ring that infect tetraodontid and diodontid fishes. Instead, Allocreadioidea should become a junior synonym of Gorgoderoidea, with Allocreadiidae included in Gorgoderoidea. Families previously included under Allocreadioidea [i.e., Opecoelidae + Opistholebetidae, Brachycladiidae Odhner, 1905, and Acanthocolpidae Lühe, 1906 (represented by Stephanostomum Looss, 1899)] should be grouped under the superfamily Brachycladioidea.

In the present work, we agree with Gibson (1996) rather than Van Cleave and Mueller (1934), Caira (1989), and Caira and Bogéa (2005) and accept Megalogonia. Megalogonia seems to be the closest genus to Crepidostomum (Figs 3 and 4). Our unpublished molecular data show variability among M. ictaluri and several species of Crepidostomum indicating possible generic-level distinction for Megalogonia, but further examination of this problem will be addressed in detail separately.

The present tree topology corroborates placement of Haploporidae and Atractotrematidae as a basal group in Xiphidiata (e.g., Olson et al. 2003); however, our trees (Figs 3 and 4) suggest that these families do not belong in Gorgoderoidea. They appear basal to a clade of the Gorgoderoidea + Plagiorchioidea (Figs 3 and 4) or at least a sister taxon to both these lineages. Therefore, we still consider Haploporidae and Atractotrematidae as sole families in the superfamily Haploporoidea (Jones 2005, Overstreet and Curran 2005).

Our analyses included the megasoline haploporid Hapladena nasoni Yamaguti, 1970 and the atractotrematid Pseudomegasolena ishigakiense Machida et Kamiya, 1976, as did the analysis of Olson et al. (2003), plus the freshwater chalcinotrematine haploporid Saccocoelioides sp. from a Central American stream. Saccocoelioides sp. grouped as a sister taxon to $H$. nasoni, confirming that Chalcinotrematinae belongs in Haploporidae. The relatively poor support for the clade containing Saccocoelioides sp. and H. nasoni suggests that Chalcinotrematinae, a subfamily primarily native to Central and South American freshwater and Megasolinae, a subfamily with members occurring in herbivorous marine reef fishes, exibit a relatively distant relationship among haploporid subfamilies. A more detailed analysis containing species from all four haploporid subfamilies (Chalcinotrematinae, Haploporinae, Waretrematinae, and Megasolinae) is currently being conducted.

\section{Biogeography}

Polylekithum catlai (Kakaji, 1969), (as Allocreadium catlai) was described from a single specimen extracted from Catla catla (Hamilton, 1822), (a cyprinid fish commonly used in
Asian aquaculture), from a river in Lucknow, India. Yamaguti (1971) considered this species to belong in Polylekithum presumably because diffuse eyespots were absent, and the species has a very short oesophagus. The illustration and brief description for the species presented by Kakaji (1969a) seems to present at least a possibility that the species belongs in Polylekithum, but only one (quite large) egg measuring 120 by $100 \mu \mathrm{m}$, rather than many eggs was in the uterus. Furthermore, the presence or absence of diffuse eyespots in the forebody is not a reliable feature to assess in this particular instance because though no diffuse eyespots are mentioned or illustrated for P. catlai by Kakaji (1969a), neither are they mentioned nor illustrated for any other species of Allocreadium that Kakaji (1969a, b) reported or described from India. That author apparently did not recognize the importance of diffuse eyespots among allocreadiids and related groups. Furthermore, several Allocreadium spp. from the fore-mentioned papers have the vitellarium extending into the forebody and/or a relatively short oesophagus, features consistent with Polylekithum but not Allocreadium (i.e., A. fasciatusi Kakaji, 1969; A. guptai Kakaji, 1969; A. handia Pande, 1937; A. thapari Gupta, 1950; A. mehrai Gupta, 1956; A. singhi Rai, 1962; and A. heteropneustusius Agrawal, 1964). Absence of specimens of $P$. catlai in lending museums and the failure by Kakaji (1969a, b) to report important morphological features distinguishing Allocreadium from Polylekithum prevent an accurate assessment of the identity of $P$. catlai at the present time.

Similar problems involving Allocreadium and Polylekithum occur in descriptions of certain South American species because parasitologists there, like earlier North American workers and those in India, did not agree on diagnostic features for Allocreadium and Polylekithum. Shimazu et al. (2000) described A. patagonicum from Percichthys colhuapiensis MacDonagh, 1955 and $P$. trucha (Valenciennes, 1833) (both Perciformes, Percichthyidae) in Argentina, in June 2000. Then in September 2000, Ostrowski de Núñez et al. (2000) described $P$. percai, also from $P$. trucha in Argentina. We examined ten paratypes of $A$. patagonicum (IPCAS D-424) and a paratype of $P$. percai (BMNH 1999.10.19.1) and determined that they belong in the same genus and perhaps may represent the same species. Both named types have vitelline follicles reaching to the pharynx, and the caecal bifurcation occurs well anterior in the forebody like in species of Polylekithum, but the oesophagus is long (not observable in the single loaned paratype of $P$. percai the metraterm is ventral to the cirrus sac and diffuse eyespots are present on the forebody, suggesting it certainly cannot be assigned to Polylekithum. The forms clearly belong in Allocreadiidae based on these features but since the vitelline follicles reach into the forebody, the specimens cannot be placed in Allocreadium. Likewise, though the forms closely resemble Creptotrema Travassos, Artigas et Pereira, 1928 , no lateral papillae are present on the oral sucker. The species therefore belongs in a yet unnamed allocreadiid genus most similar to Creptotrema. Perhaps the forms should be compared with Paracreptotrema Choudhury, Pérez-Ponce de 
León, Brooks et Daverdin, 2006. Regardless, for the time being we consider the two named species to represent one species, $A$. patagonicum, making $P$. percai a junior synonym. Since the species does not conform to the generic diagnosis of Allocreadium (see Caira and Bogéa 2005), we consider the species incertae sedis. Flores et al. (2004) described a similar species, $A$. pichi from the freshwater smelt Galaxias maculatus (Jenyens, 1842) (Osmeriformes), from lake Moreno in Argentina. We examined a paratype of $A$. pichi (BMNH 2004.1.16.1-2) and determined that it does not differ appreciably from $A$. patagonicum except that the ventral sucker is relatively larger. In any event, we consider this a second species in the yet unnamed Creptotrema-like genus. Polylekithum therefore does not have representation in South America. Perhaps future molecular gene sequence comparison between the two North American species and the single questionable Indian species or a similar Indian species will provide enough evidence to corroborate our speculation.

As inclusion of more taxa, especially controversial ones, into the phylogeny of the Digenea occurs, a more accurate topology emerges. The present analysis provides a more accurate estimation of interrelationships among some members of Xiphidiata than previously available. Based on the results of the present analysis, we believe that Polylekithum contains two North American species and belongs in an undetermined family along with at least Caudouterina. The family is closely related to Encyclometridae and belongs in Gorgoderoidea. Furthermore, Callodistomidae and Allocreadiidae represent sister clades, also in Gorgoderoidea, and Allocreadioidea is rendered a junior synonym of Gorgoderoidea. Haploporidae and Atractotrematidae, formerly included in Gorgoderoidea by some authors, belong in Haploporoidea, a basal superfamily in Xiphidiata.

Acknowledgements. The following people kindly assisted with North American fish collecting or provided us with fish they caught: Scott D. Snyder (University of Nebraska at Omaha), Michael A. Barger (Peru State College), Ronnie Palmer, Larry Nicholson, Karl Manning, Jimmy Christmas, Jody Peterson (Gulf Coast Research Laboratory), and Andres Soto (Texas A\&M University, Kingsville). We are especially indebted to Jose Bernardo Ortega Gonzales of Universidad [Internacional de la Integración de América Latina (UNIVAL), Chinandega, Nicaragua] and Lesber Salezar (Langostinos de Centroamerica), formerly of UNIVAL, Chinandega, Nicaragua for their generous hospitality and for facilitating collections used in this study. We were grateful for the use of facilities at the University of Tennessee-Martin's Reelfoot Lake Research and Teaching Station in Samburg, Tennessee, and we greatly appreciated the hospitality afforded us by Andrew Hammond, the refuge manager at the Catahoula National Wildlife Refuge. Janine Caira (University of Connecticut) provided laboratory space for processing and observing specimens. Jeffrey Bell and Kenneth Drees (both from University of North Dakota) provided technical help with specimen preparation for molecular comparisons and analyses. Mrs. E.A. Harris (The Natural History Museum, London) and Dr. František Moravec (Institute of Parasitology, Academy of Sciences of the Czech Republic) kindly loaned us paratype specimens. We also thank F. Agustín Jiménez-Ruiz (Harold W. Manter Laboratory at the Nebraska State Museum, University of Nebraska, Lincoln) and Mrs. Patricia A. Pilitt (United States National Parasite Collection, Belts- ville) for assisting SSC and providing him bench space at the museums. Material is based upon work supported by the National Science Foundation under North Dakota EPSCoR Grant No. 0132289 to VVT and under NSF Grant Nos. 0529684 and 0608603 to RMO.

\section{References}

Arnold J.G. 1934. Some trematodes of the common bullhead Ameiurus nebulosus (Le Sueur). Transactions of the American Microscopical Society, 53, 267-276.

Cable R.M. 1956. Opistholebes diodontis n. sp., its development in the final host, the affinities of some amphistomatous trematodes from marine fishes and the allocreadioid problem. Parasitology, 46, 1-13.

Caira J.N. 1989. A revision of the North American papillose Allocreadiidae (Digenea) with independent cladistic analyses of larval and adult forms. Bulletin of the University of Nebraska State Museum, 11, 1-91.

Caira J.N., Bogéa T. 2005. Family Allocreadiidae Looss, 1902. In: Keys to the Trematoda. Vol. 2 (Eds. A. Jones, R.A. Bray and D.I. Gibson). CABI Publishing, Wallingford, UK, 417-436.

Clopton R.E. 2004. Standard nomenclature and metrics of plane shapes for use in gregarine taxonomy. Comparative Parasitology, 71, 130-140.

Flores V.R., Brugni N., Ostrowski de Núñez M. 2004. Allocreadium pichi n. sp. (Trematoda: Allocreadiidae) in Galaxias maculatus (Osteichthyes: Galaxiidae) from Lake Moreno in Patagonia (Argentina). Systematic Parasitology, 58, 217-221.

Gibson D.I. 1996. Trematoda. In: Guide to the parasites of fishes of Canada. Part IV (Eds. L. Margolis and Z. Kabata). Canadian Special Publication of Fisheries and Aquatic Sciences, 124.

Harwood P.D. 1935. Maculifer chandleri, n. sp. (Allocreadiidae), a trematode from Texas catfish. Helminthological Society of Washington, 2, 75-76.

Hoffman G.L. 1999. Parasites of North American freshwater fishes. Cornell University Press.

Jeanmougin F., Thompson J.D., Gouy M., Higgins D.G., Gibson T.J. 1998. Multiple sequence alignment with ClustalX. Trends in Biochemical Sciences, 23, 403-405.

Jones A. 2005. Superfamily Haploporoidea Nicoll, 1914. In: Keys to the Trematoda. Vol. 2 (Eds. A. Jones, R.A. Bray and D.I. Gibson). CABI Publishing. Wallingford, UK, 127-128.

Jousson O., Bartoli P. 2001. Molecules, morphology and morphometrics of Cainocreadium labracis and Cainocreadium dentecis n. sp. (Digenea: Opecoelidae) parasitic in marine fishes. International Journal for Parasitology, 31, 706-714.

Jousson O., Bartoli P. 2002. Species diversity among the genus Monorchis (Digenea: Monorchiidae) parasitic in marine teleosts: molecular, morphological and morphometrical studies with a description of Monorchis blennii n. sp. Parasitology Research, 88, 230-241.

Kakaji V.L. 1969a. Studies on helminth parasites of Indian fishes. Part III. Some trematode parasites of fresh water fishes of Uttar Predesh. Indian Journal of Helminthology, 21, 49-80.

Kakaji V.L. 1969b. Studies on helminth parasites of Indian fishes Part III. On some species of the genus Allocreadium Looss, 1900. Annales de Parasitologie Humaine et Comparée (Paris), 44, 131-146.

Kohn A., Fernandes B.M.M. 1976. Sobre uma nova espécie do gênero Leurosoma Ozaki, 1932 (Trematoda, Allocreadiidae) parasito de ofidio. Atas da Sociedade de Biologia do Rio de Janeiro, 18, 87-89.

Maddison D.R., Maddison W.P. 2000. MacClade4: analysis of phylogeny and character evolution. Sinauer Associates, Sunderland, Massachusetts, USA. 
Manter H.W. 1970. The terminology and occurrence of certain structures of digenetic trematodes, with special reference to the Hemiuroidea. In: H.D. Srivastava Commemorative Volume (Eds. K.S. Singh and B.K. Tandon). Indian Veterinary Research Institute, Izatnagar, 27-33.

Martin G.W. 1966. Caudouterina rhyacotritoni gen. et sp. n. (Trematoda: Digenea) from the Olympic salamander. Journal of Parasitology, 52, 935-938.

Mueller J.F., Van Cleave H.J. 1932. Parasites of Oneida Lake fishes. Part II. Roosevelt Wild Life Annals, 3, 73-154.

Odening K. 1960. Der Ansatzmodus des Exkretionsgefässsystem und die systematische Stellug von Encyclometra (Trematoda, Digenea). Monatsberichte der Deutschen Akademie der Wissenschaften zu Berlin, 2, 445-449.

Odening K. 1968. Exkretionssystem und systematische Stellung der Trematodengattungen Anchitrema, Cephalogonimus, Encyclometra, Mesotretes, Omphalometra und Urotrema. Monatsberichte der Deutschen Akademie der Wissenschaften zu Berlin, 10, 492-498.

Olson P.D., Cribb T.H., Tkach V.V., Bray R.A., Littlewood D.T.J. 2003. Phylogeny and classification of the Digenea (Platyhelminthes: Trematoda). International Journal for Parasitology, 33, 733-755.

Olson P.D., Tkach V.V. 2005. Advances and trends in the molecular systematics of the parasitic Platyhelminthes. Advances in Parasitology, 60, 165-243.

Ostrowski de Núñez M., Brugni N., Viozzi G. 2000. Polylekithum percai n. sp. (Trematoda: Allocreadiidae) from Percichthys trucha (Perciformes: Percichthydae) in Patagonia, Argentina, and a redescription of Homalometron papilliferum (Szidat, 1956) n. comb. Systematic Parasitology, 47, 51-57.

Overstreet R.M., Curran S.S. 2005. Family Haploporidae Nicoll, 1914. In: Keys to the Trematoda. Vol. 2 (Eds. A. Jones, R.A. Bray and D.I. Gibson). CABI Publishing, Wallingford, UK, 129-174.

Overstreet R.M., Curran S.S., Pote L.M., King D.T., Blend C.K., Grater W.D. 2002. Bolbophorus damnificus n. sp (Digenea: Bolbophoridae) from the channel catfish Ictalurus punctatus and American white pelican Pelecanus erythrorhynchos in the USA based on life-cycle and molecular data. Systematic Parasitology, 52, 81-96.

Pearse A.S. 1924. Observations on parasitic worms from Wisconsin fishes. Transactions of the Wisconsin Academy of Sciences, Arts, and Letters, 21, 147-160.

Peters L.E. 1961. The genus Skrjabinopsolus (Trematoda: Digenea), with reference to the allocreadioid problem. American Midland Naturalist, 65, 436-445.
Platt T.R., Tkach V.V. 2003. Two new species of Choanocotyle Jue Sue and Platt, 1998 (Digenea: Choanocotylidae) from an Australian freshwater turtle (Testudines: Pleurodira: Chelidae). Journal of Parasitology, 89, 145-150.

Platta C.S., Choudhury A. 2006. Systematic position and relationships of Paracryptotrematina limi, based on partial sequences of 28S rRNA and cytochrome c oxidase subunit 1 genes. Journal of Parasitology, 92, 411-413.

Seitner P.G. 1951. The life history of Allocreadium ictaluri Pearse, 1924 (Trematoda: Digenea). Journal of Parasitology, 37, 223-244.

Shimazu T., Urawa S., Coria C.O. 2000. Four species of digeneans, including Allocreadium patagonicum sp. n. (Allocreadiidae), from freshwater fishes of Patagonia, Argentina. Folia Parasitologica, 47, 111-117.

Snyder S.D., Tkach V.V. 2001. Phylogenetic and biogeographical relationships among some holarctic frog lung flukes (Digenea: Haematoloechidae). Journal of Parasitology, 87, $1433-1440$.

Swofford D.L. 2002. PAUP* version 4.0b10: phylogenetic analysis using parsimony (and other methods). Sinauer Associates, Sunderland, Massachusetts, USA.

Tkach V.V., Pawlowski J. 1999. A new method of DNA extraction from the ethanol-fixed parasitic worms. Acta Parasitologica, 44, 147-148.

Tkach V.V., Pawlowski J., Mariaux J., Swiderski Z. 2001. Molecular phylogeny of the suborder Plagiorchiata and its position in the system of Digenea. In: Interrelationships of the Platyhelminthes (Eds. D.T.J. Littlewood and R.A. Bray). Taylor \& Francis, London, 186-193.

Tkach V.V., Pawlowski J., Sharpilo V.P. 2000. Molecular and morphological differentiation between species of the Plagiorchis vespertilionis group (Digenea, Plagiorchiidae) occurring in European bats, with a re-description of $P$. vespertilionis (Muller, 1780). Systematic Parasitology, 47, 9-22.

Tkach V.V., Littlewood D.T.J., Olson P.D., Kinsella J.M., Swiderski Z. 2003. Molecular phylogenetic analysis of the Microphalloidea Ward, 1901 (Trematoda: Digenea). Systematic Parasitology, 56, 1-15.

Van Cleave H.J., Mueller J.F. 1934. Parasites of Oneida Lake fishes. Part III. Roosevelt Wild Life Annals, 3, 159-334.

Yamaguti S. 1958. Systema helminthum. Vols 1 and 2. The digenetic trematodes of vertebrates. Interscience Publishers Inc., New York.

Yamaguti S. 1971. Synopsis of digenetic trematodes of vertebrates. Vols I and II. Keigaku, Tokyo. 